\title{
The physician's unique role in preventing violence: a neglected opportunity?
}

\author{
John C Umhau ${ }^{1 *}$, Karysse Trandem ${ }^{2}$, Mohsin Shah $^{3}$ and David T George ${ }^{1}$
}

\begin{abstract}
Background: Episodes of explosive rage and violence comprise a symptom complex which can have a devastating effect on a person's life. In the community this behavior is seen as workplace violence, domestic abuse and road rage, while in the clinical setting, this behavior is rarely mentioned by patients, despite evidence that it can signify an important biological disorder that may afflict more than three percent of the population.

Discussion: Patients are often reluctant to seek help for episodic attacks of rage, especially attacks which are accompanied by physical violence. Although, in the past, clinicians have had few treatment options to offer, recent neuroscience advances have created new possibilities to understand and help patients with this neglected problem. No formal medical guidelines for treating violence exist; however, many patients can be helped by diagnosis, referral and treatment. Treatment can include pharmaceuticals and nutrients, as well as referral for anger management or behavioral therapy.

Summary: The astute clinician has an opportunity to positively impact an important problem through the diagnosis and treatment of patients with symptoms of intermittent explosive disorder.
\end{abstract}

Keywords: aggression, alcoholism, psychopharmacology, violence, domestic abuse, prevention, neurobiology, treatment, domestic violence

\footnotetext{
* Correspondence: umhau@jhu.edu

'Laboratory of Clinical and Translational Studies, National Institutes of Health, National Institute on Alcohol Abuse and Alcoholism, 10 Center Drive, Building 10-CRC Hatfield Center, Room 1-5330, Bethesda, MD, 20892-1108, USA

Full list of author information is available at the end of the article
}

\section{Background}

The symptom complex characterized by repeated episodes of explosive rage and violence, disproportionate to any provocation, is rarely a patient's chief complaint, but it is a common problem none the less. For the afflicted individual, such a complaint may have profound effects on their self-esteem, their interpersonal relationships, and even on their ability to function in society. While some violence can be premeditated, goal directed or related to antisocial, callous unemotional traits, it is rather the category of violence described as affective aggression, (that is, reactive, defensive or hostile aggression) associated with fear and threat which will be the focus of this paper [1]. For most clinicians, the clinical perspective of violence as seen with Intermittent Explosive Disorder, specified by DSM-IV to encompass "several discrete episodes of failure to resist aggressive impulses that result in serious assaultive acts or destruction of property", with the further specification that "the degree of aggressiveness expressed during the episodes is grossly out of proportion to any precipitating psychological stressors" [2], provides a framework for addressing this issue from a clinical standpoint. When afflicted individuals express a concern about this unwanted behavior, it becomes an issue which clearly warrants the concern of their physician. This paper will give a brief review of the clinical approach to this, often ignored, yet common problem.

Intermittent explosive disorder has a prevalence of 3.9\%, suggesting that each year in the United States, it is responsible for more than 30 million violent assaults [3]. When manifested as domestic abuse, road rage or workplace violence, such behavior is commonly attributed to cultural factors, social stress, economic deprivation or substance abuse. Much more needs to be known about these behaviors; however, recent advances in neuroscience allow for a more complete understanding, which accounts for biological factors amenable to medical treatment [4-8].

A number of factors have limited the benefits which a neurobiological perspective on violence might bring. 
Perpetrators may be unaware that they could benefit from medical intervention. Clinicians may be uncomfortable dealing with an area of diagnosis and treatment with which they are unfamiliar. Considering a violent perpetrator to be responsible for their actions may be a critical legal policy to uphold, but such a policy may impede diagnosis. All these factors ultimately work together to deny the benefits of modern clinical care to individuals who may urgently need it.

This article will provide a brief overview of the diagnosis and treatment of chronic violent behavior. A brief discussion of the neurobiology of violence will be presented and legal aspects of treatment will also be discussed in an effort to encourage clinical interest in what may be one of the most neglected areas of medicine.

\section{Discussion \\ Neurobiology}

One way to understand the biological basis for explosive types of rage and violence is to consider it as behavior which promotes survival in the face of threat [6]. Although many "threats" are psychological, rather than physical, the autonomic nervous system is aroused in either case. The resulting rage response is an innate behavior that rises from the limbic system (for example, amygdale and related structures) and is associated with palpitations, sweating, tachypnea and trembling $[9,10]$. The individual's own perception of these symptoms may incite further arousal in a positive feedback loop on the limbic system response. The prefrontal cortex and the anterior cingulate gyus provide a "top-down" inhibition of this limbic response while evaluating whether a physical or psychological "threat" is a harmless insult or a serious challenge to survival [9]. Controlling this limbic response appropriately is one of the most time critical functions of the frontal cortex; the serotoninergic neurotransmitter system is thought to be critical in this process [11]. The rapid appraisal of potential threats is especially sensitive to perturbation, such as the sensory processing distortions caused by metabolic disturbances or substance abuse [9]. It is the prefrontal cortex which allows for the consideration of nuanced and nonviolent responses to any specific "threat" [12]. However, when violence is called for, limbic (for example, amygdale) activation will shut down the calming input from the prefrontal cortex in order to promote quick reactions and efficient fighting [13].

Various neurological disorders can disrupt the critical and sensitive processing necessary for appropriate behavior in response to perceived threat [9]. Neuroimaging studies suggest that in the pathological situation, calming cortical inputs are shut down when they should not be, permitting exaggerated and inappropriate limbic arousal and rage $[8,12]$. Impaired control of the limbic system rage response in this situation explains how a domestic violence perpetrator could physically attack their spouse with no apparent concern for the consequences. If cortical control is dysfunctional, relatively minor slights to the ego might be misinterpreted as overwhelming threat, leading to a violent response [12]. Acute psychological stress as well as social and cultural factors may interact with neurobiological deficits to create a situation where inappropriate violence becomes frequent [14].

\section{Diagnosis}

Episodes of explosive rage and violence can be a defining feature of a patient's personal life; however, in the same way that patients can be reluctant to admit they have depression; they are even more ashamed to admit they have violent behavior. Often patients experience remorse, but not always. Simply asking during a history and physical examination, "Do you lose your temper? Do you do things when you are angry that you later regret?" can lead an individual to discuss behaviors that they would otherwise never initiate. If a clinician can suspend judgment about their patient's behavior and discuss situations without making disparaging remarks, patients can potentially overcome their denial and face the destructive effects of their "anger problem". The use of valid scales, such as the STAXI [15] and the BPAQSF [16] may also be helpful in identifying such patients. Between episodes, there is no classical way for someone with rage and violence to present for care; however, considering the association between violence and alcohol, individuals undergoing alcoholism detoxification may be more likely to benefit from screening. Impulsive aggression is frequently found in a co-morbid association with substance abuse and with personality disorders. Also, patients presenting with injuries suffered as a result of interpersonal violence are themselves at risk for having inappropriate attacks of rage [17]. When patients do present with violence, it is a common cause for involuntary commitment to a psychiatric facility and acute therapy $[18,19]$.

Although in many cases violence may be a behavior simply learned from the patient's social and cultural background, the unique role of the clinician is to critically evaluate each patient for biological factors which can be treated, or refer the patient to a physician who can [20-24]. Many disorders which affect the central nervous system have been associated with violence [20,25-29]. Episodic attacks of rage and violence are not a classic presentation of any specific disorder, but this behavior can arise from diverse causes, including epilepsy, nutritional deficiencies, brain tumors, toxic exposures and encephalopathy from endocrine, metabolic or infectious disorders [18]. Closed head injuries can leave patients with no objective sign of their injury but with a dramatic predilection for episodes of impulsive rage [27]. 
Both acute and chronic substance abuse, for example, alcohol, and stimulants, can contribute to violence [30]. Depression, mania, post-traumatic stress disorder and schizophrenia may be associated with irritably, rage and violence [20]. (See Table 1)

It is important to note that not all instances of violence have serious underlying pathology. For example, the aggression associated with hypoglycemia can be simply treated with food. Identifying the precise biological factors contributing to violence can be difficult as multiple predisposing conditions often coexist in one patient. As with any neurological issue, diagnostic testing is led by the symptom presentation and physical exam. For example, if temporal lobe seizures are suspected, an electroencephalogram (EEG) may be indicated [26]. In most cases, however, the physical exam will be normal, and a precise diagnosis will be elusive. In such a situation, empiric treatment may be indicated.

\section{Treatment}

Although no drugs have a Food and Drug Administration (FDA) approved indication for violence, many therapeutic options have been tested in randomized, placebocontrolled double-blind trials [20,28,31]. (see Table 2) Psychiatrists use various classes of drugs as treatment for violence, but treatment guidelines have not been established. The point of this article is to introduce existent therapeutic options rather than to provide a detailed review of pharmacotherapy, which has been reviewed elsewhere [18,20,25,31-40]. Medication is not a panacea; all types of violence are not amenable to pharmacological therapy. For example, treatment with the classic anticonvulsant phenytoin was shown to reduce impulsive but not premeditated violence [41]. In previous reviews the use of anticonvulsants, beta blockers and atypical antipsychotic agents has been described in detail [20,31,40-49]. For more than 40 years, lithium has been used in many populations to treat violence [50].
Serotonin reuptake inhibitors are commonly used in the setting of depression but can also be effective for reducing chronic anger [20]. Serotonin reuptake inhibitors are often initially used at low doses to guard against any paradoxical exacerbating effect $[31,22,41]$. Since the use of all of these medications for reducing violence is "off label", it is important to carefully monitor for any adverse effects which can in some instances cause an increase in irritability and aggression $[22,40]$.

Nutritional factors, especially the essential omega-3 fatty acids, docosahexaenoic acid (DHA) and eicosapentaenoic acid (EPA) are critical components of the nervous system, but can be deficient in the diet [51-53]. Some controlled trials suggest that these nutrients may reduce aggression and produce other benefits with few side effects [54-56]. In recognition of this, the American Psychiatric Association recommends that individuals with mood, impulse-control or psychotic disorders consume 1 gram of EPA + DHA per day [57]. When essential fatty acids were administered with multiple vitamins to young men in prison, violence was reduced by one third [58], a finding which was later replicated [59]. Although there are many more studies demonstrating the effectiveness of prescription pharmaceuticals than there are of studies testing nutrients, omega- 3 fatty acid (that is, fish oil) and vitamins have the benefit that they may be readily accepted by patients who desire a more "natural" type of therapy without the stigma and serious side effects which sometimes accompany psychotropic medications [60]. Because of the potential for nutritional therapy to address the problem of violence on a public health basis, there is a critical need for more research to resolve controversies in this area.

\section{Substance abuse treatment as therapy for aggressive behavior}

Alcoholism may be the most common condition associated with violence; alcohol is thought to have a

\section{Table 1 Some medical conditions associated with episodic rage and violence}

\begin{tabular}{ll}
\hline Psychiatric & $\begin{array}{l}\text { Organic brain syndrome [35], Korsakoff's psychosis [86], bipolar disorder [87], psychoactive substance intoxication and } \\
\text { withdrawal [88], psychotic disorders [89], premenstrual dysphoric disorder [90], post-traumatic stress disorder [22], panic } \\
\text { disorder [4], generalized anxiety disorder [91], antisocial personality disorder [92], borderline personality disorder [92], } \\
\text { personality disorders [92], attention deficit disorder [93], major depressive disorder [94]. }\end{array}$ \\
\hline Neurological & Brain tumors/lesions [95], head injury [27], Parkinson's disorder [96], seizure disorder [26], multiple sclerosis [97], normal pressure \\
& hydrocephalus [98], autism [34], Wilson's disease [29], Huntington's disease [99], dementia [100], stroke [101]. \\
\hline $\begin{array}{l}\text { Nutritional } \\
\text { deficiency }\end{array}$ & Omega-3 fatty acids [56], folate [29], cobalamin (B12) [102,103], thiamine [104,105], iron [106], lithium [107], magnesium [53,108], \\
\hline Medical and toxic & Alcohol [21,110], cocaine [21,111], manganese [29,112], organophosphorous compounds [29,113], phencyclidine (PCP) [114], \\
& lysergic acid diethylamide (LSD) [101,115], heroin [101,116], amphetamines [117], benzodiazepines [117,118], prescription drugs \\
& {$[117,119]$, anabolic steroids [117]. } \\
\hline Metabolic/ & Hypoglycaemia [101,117,120], hepatic encephalopathy [121], fluid and electrolyte imbalances [119], disorders of the thyroid, \\
Endocrine & parathyroid and adrenal glands [29,122], hypoxia [101]. \\
\hline Miscellaneous & Intermittent Porphoria [123], chronic pain [124], sleep disorders [29,125], anemia [126], vasculitis [119], meningitis/encephalitis \\
& {$[101]$, syphilis [102]. }
\end{tabular}


Table 2 Examples of some agents used to reduce violence and aggression

\begin{tabular}{ll}
$\begin{array}{l}\text { Medications for } \\
\text { alcoholism }\end{array}$ & $\begin{array}{l}\text { Naltrexone and acamprosate in sober alcoholics to reduce craving and relapse [63,64]; prazosin in alcoholism with PTSD } \\
\text { for caving and relapse [127]. }\end{array}$ \\
\hline Nutritional factors & $\begin{array}{l}\text { Essential omega } 3 \text { fatty acids, docosahexaenoic acid (DHA) and eicosapentaenoic acids (EPA) in bipolar disorder and } \\
\text { borderline personality disorder; multiple vitamins and minerals with DHA and EPA in young male prisoners, and in children } \\
{[53,57-59,128] .}\end{array}$ \\
\hline $\begin{array}{ll}\text { In children and adults, in personality disorders, and in combination with other anticonvulsants or atypical antipsychotics } \\
{[40,48] .}\end{array}$ \\
\hline Beta-blockers & Propranolol in brain-injury, autism, schizophrenia, organic mental disorders [37,129]. \\
\hline Anticonvulsants & $\begin{array}{l}\text { Carbamazepine/oxcarbazepine in impulsive violence and in elderly [32,36]; phenytoin in prisoners and in intermittent } \\
\text { explosive disorder [32,38,49,130]; Topriamate in borderline personality disorder and in depression [40]; valproate/divalproex }\end{array}$ \\
\hline in a variety of psychiatric conditions [32,40]. \\
\hline Antidepressants & $\begin{array}{l}\text { Flouxetine in personality disorders [131], and in domestic abuse when combined with Cognitive Behavioral Therapy (CBT) } \\
\text { and alcohol treatment [132]; trazodone in dementia associated aggression [133]. }\end{array}$ \\
\hline $\begin{array}{l}\text { Atypical } \\
\text { antipsychotics }\end{array}$ & $\begin{array}{l}\text { Clozapine in schizophrenia [33,134]; quetiapine in schizophrenia and bipolar disorder [33,40]; Loxapine in schizophrenic and } \\
\text { psychosis [40], olanzapine in schizophrenia and borderline personality disorder [33,40]; aripiprazole in schizophrenia, autism } \\
\text { spectrum disorders and borderline personality disorder [33,40]; risperidone in a variety of psychiatric illness [40]. }\end{array}$ \\
\hline
\end{tabular}

disinhibiting effect on aggressive behavior [6]. Reports suggest that most severe interpersonal violence occurs when the perpetrator is intoxicated. Cocaine abuse is also associated with violence [30]. Not surprisingly, recent research has found that substance abuse treatment can reduce the prevalence of violent behavior by more than half [61]. Patients can be referred to specific substance abuse treatment programs as well as to selfhelp programs such as Alcoholics Anonymous. Medical management of alcoholism is effective and can include the use of naltrexone or acamprosate [62]. These drugs are relatively underused medications which can reduce the incidence of relapse to alcoholic drinking [63]. Side effects are relatively minor, and in some alcoholics, these drugs can have a marked effect [64].

\section{Psychological intervention as a treatment for aggression}

In addition to any prescribed medical treatment, patients must recognize their need to change, assume responsibility for their behavior and begin to deal with conflict in a positive manner. To facilitate these cognitive processes, violent individuals are commonly offered anger management or behavioral therapies [65-68].

Psychological interventions can be very helpful for some aggressive individuals [69], and effects can last for months, even years after the therapy is terminated [66-68]. In a meta-analysis looking at 50 studies, angry, (and in some cases violent), patients treated with a variety of cognitive behavioral therapy (CBT) treatments had better outcomes than $76 \%$ of non-treated control patients [70]. These studies considered inpatients and outpatients, children and adults, abusive parents and spouses, prisoners and individuals with mental retardation as well as the general population. The most effective CBT anger management programs include two or all three of the following components: relaxation techniques, cognitive interventions and communication skills [71]. For individuals with borderline personality disorder, dialectical-behavioral therapy (DBT) is an effective therapy [72,73]. The success of psychological interventions on domestic violence recidivism is controversial, but a meta-analysis of 22 studies suggests that the effect size of therapy is generally significant though small [65]. Treatments specifically for domestic violence include feminist psycho-educational men's groups, (that is, the Duluth model) [68], men's CBT groups, anger management and couples' therapy [65]. Many states regulate the therapy of domestic abusers and, in some cases, restrict the use of couple's therapy or the consideration of neuropsychiatric issues (for example, alcoholism); the extent to which such legislation inhibits potentially beneficial treatment has not been evaluated [74]. Recently, a computer assisted treatment adjunct based on a Trans Theoretical Model of behavior change has been shown to reduce violence, suggesting that entirely new treatment paradigms could be developed in the future [75]. The effectiveness of domestic violence treatment is difficult to study, and the problem is compounded by the effect of high dropout rates ( $40 \%$ to $60 \%$ within three months), which predict poor outcome [69]. A positive correlation has been found repeatedly between the strength of the therapeutic alliance, patient attendance rates and the overall likelihood of the participant benefiting from the treatment $[76,77]$. Therefore, when referring aggressive patients for therapy, a physician should supply several options and emphasize the importance of finding a therapist with whom the patient feels comfortable. In the United States, the American Psychological Association (1-800-964-2000) or the National Domestic Violence Hotline (1-800-799-SAFE) can provide referral information.

\section{Legal and ethical issues in the United States}

While the American Medical Association's Ethics Code requires and emphasizes the importance of patient confidentiality, it also states the following: "When a patient 
threatens to inflict serious bodily harm to another person or to him or herself and there is a reasonable probability that the patient may carry out the threat, the physician should take reasonable precautions for the protection of the intended victim, which may include notification of law enforcement authorities..." (E-5.05 Confidentiality). Additionally, in the landmark Tarasoff cases (Tarasoff $\mathrm{v}$. Regents of the University of California 1974 and 1976) [78] the ruling established in the state of California a legal duty of health workers to warn and protect potential victims from a patient's foreseeable violence. Since then, some states have codified the health worker's duty to protect specifying how to discharge that duty, some states have declined to uphold the duty to protect in court and some states have not addressed the issue in court or legislation [79]. In states where the duty to protect does apply it is only operative when the patient identifies a specific victim or has a history of violence and there is substantial and compelling reason to believe that the patient will be violent again. The health worker fulfils the duty in most states by informing the relevant authorities, warning the victim or having the patient hospitalized, although a few states have additional requirements. For victims who are minors, all 50 states have passed some form of a mandatory abuse and neglect reporting law. Some states mandate that the suspicion of domestic violence or elder abuse must be reported to the legal authorities [80]. All states require reporting of suspected child abuse [81]. When treating an adult victim, mandatory reporting laws also vary by state and are based on the type and circumstances of the injury; laws in all states are listed in a 2002 article by Houry and colleagues [82]. For more information on legal responsibilities as a physician, the American Medical Association recommends contacting the state licensing board. Screening a patient for violent activity can be unethical if a physician fails to discuss the limits of confidentiality and any legal requirement of the state to break confidentiality and involve the legal system [83].

While knowledge of laws in one's state of practice is essential, experts in medical law strongly recommend that clinicians approach the dangerousness of a patient as a clinical rather than legal issue $[79,84,85]$. The primary determinants in a malpractice suit are the thoroughness of the clinicians' assessment of a patient's potential for violence and the care with which options of action were considered, rather than the accuracy of the clinicians' predictions [79]. Thorough mental status examinations and substance use histories should be documented with direct quotes from the patient. Careful notes should be taken explaining why a certain course of action was taken, what other options were considered but opted against and why. The more potentially dangerous the client, the more care one should take in the documentation of the case [85].

\section{Summary}

Although it is unknown what proportion of explosive rage and violent behavior can be successfully treated, the price of ignoring treatment includes the staggering cost of injuries that might be prevented, and an even greater cost in shattered communities, broken families and personal suffering. Various neurobiological disorders can affect the processing of perceived threats by the brain, leading to dysfunctional, violent behaviors. Future research will add to our understanding of violence, but existing evidence clearly shows that physicians today have a unique opportunity to address medical aspects of this problem when they identify the perpetrators of explosive violent behavior. Asking patients if they lose their temper can identify violent individuals in a non-judgmental way and can open the door to appropriate medical evaluation, treatment and referral. Patients are given an important degree of self-determination when they are offered expanded treatment options that include not only behavioral therapy, but also nutritional supplementation, alcoholism treatment and pharmaceuticals.

\section{Abbreviations}

CBT: Cognitive Behavioral Therapy; DBT: dialectical behavior therapy; DHA: docosahexaenoic acid; EPA: eicosapentaenoic acids; FDA: Food and Drug Administration.

\section{Acknowledgements}

The work was done at and supported by the National Institute on Alcohol Abuse and Alcoholism of the National Institutes of Health. The authors wish to thank Monte Philips, Tricia Umhau, Laura Kwako, PhD, and Steven Aden, JD for their helpful comments.

\section{Author details}

'Laboratory of Clinical and Translational Studies, National Institutes of Health, National Institute on Alcohol Abuse and Alcoholism, 10 Center Drive, Building 10-CRC Hatfield Center, Room 1-5330, Bethesda, MD, 20892-1108, USA. ${ }^{2}$ Department of Obstetrics and Gynecology, Grand Itasca Clinic and Hospital, 1601 Golf Course Road, Grand Rapids, MN 55744, USA. ${ }^{3}$ Medical College, CMH Lahore Medical College, University of Health Sciences, Abdur Rahman Road, Cantt, Lahore, Punjab, 54000, Pakistan.

\section{Authors' contributions}

JCU conceptualized, wrote and edited the manuscript. KT and MS wrote and edited the manuscript. DTG provided intellectual background and assisted in writing and editing the manuscript. All authors read and approved the final manuscript.

\section{Authors' information}

The authors alone are responsible for the content and writing of this commentary. JCU is certified in both Public Health and Addiction Medicine, and conducts clinical research in neuroscience at the National Institutes of Health where he has studied violence, nutrition, and alcoholism. He has more than 20 years' experience treating homeless patients. $K T$ is certified in Obstetrics and Gynecology. MS is a medical student from CMH Lahore Medical College, University of Health Sciences, Lahore, Pakistan. DTG is certified in Psychiatry and conducts clinical research at the National 
Institutes of Health where he has studied domestic violence and new treatments for alcoholism.

\section{Competing interests}

The authors declare that they have no competing interests.

Received: 30 July 2012 Accepted: 23 November 2012 Published: 23 November 2012

\section{References}

1. Siegel A, Victoroff J: Understanding human aggression: new insights from neuroscience. Int J Law Psychiatry 2009, 32:209-215.

2. American Psychiatric Association, Task Force on D-I: Diagnostic and statistical manual of mental disorders: DSM-IV-TR. Arlington, VA: American Psychiatric Publishing, Inc.; 2000.

3. Kessler RC, Coccaro EF, Fava M, Jaeger S, Jin R, Walters E: The prevalence and correlates of DSM-IV intermittent explosive disorder in the National Comorbidity Survey Replication. Arch Gen Psychiatry 2006, 63:669-678.

4. George DT, Anderson P, Nutt D, Linnoila M: Aggressive thoughts and behavior: another symptom of panic disorder? Acta Psychiatr Scand 1989, 79:500-502.

5. George DT, Hibbeln JR, Ragan PW, Umhau JC, Phillips MJ, Doty L, Hommer D, Rawlings RR: Lactate-induced rage and panic in a select group of subjects who perpetrate acts of domestic violence. Biol Psychiatry 2000, 47:804-812.

6. George DT, Phillips MJ, Doty L, Umhau JC, Rawlings RR: A model linking biology, behavior and psychiatric diagnoses in perpetrators of domestic violence. Med Hypotheses 2006, 67:345-353.

7. George DT, Umhau JC, Phillips MJ, Emmela D, Ragan PW, Shoaf SE, Rawlings RR: Serotonin, testosterone and alcohol in the etiology of domestic violence. Psychiatry Res 2001, 104:27-37.

8. George DT, Rawlings RR, Williams WA, Phillips MJ, Fong G, Kerich M, Momenan R, Umhau JC, Hommer D: A select group of perpetrators of domestic violence: evidence of decreased metabolism in the right hypothalamus and reduced relationships between cortical/subcortical brain structures in position emission tomography. Psychiatry Res 2004, 130:11-25.

9. Siever LJ: Neurobiology of aggression and violence. Am J Psychiatry 2008, 165:429-442.

10. Davis M, Rainnie D, Cassell M: Neurotransmission in the rat amygdala related to fear and anxiety. Trends Neurosci 1994, 17:208-214.

11. Davidson RJ, Putnam KM, Larson CL: Dysfunction in the neural circuitry of emotion regulation-a possible prelude to violence. Science 2000, 289:591-594.

12. Bufkin JL, Luttrell VR: Neuroimaging studies of aggressive and violent behavior: current findings and implications for criminology and criminal justice. Trauma Violence Abus 2005, 6:176-191.

13. Garcia R, Vouimba RM, Baudry M, Thompson RF: The amygdala modulates prefrontal cortex activity relative to conditioned fear. Nature 1999, 402:294-296.

14. Eysenck HJ: The origins of violence. J Med Ethics 1979, 5:105-107.

15. Forgays DG, Forgays DK, Spielberger CD: Factor structure of the State-Trait Anger Expression Inventory. J Pers Assess 1997, 69:497-507.

16. Diamond PM, Magaletta PR: The short-form Buss-Perry Aggression Questionnaire (BPAQ-SF): a validation study with federal offenders. Assessment 2006, 13:227-240.

17. Dutton DG: My back pages: reflections on thirty years of domestic violence research. Trauma Violence Abus 2008, 9:131-143.

18. Simon Rl, Tardiff K: In Textbook of Violence Assessment and Management Volume 355. Arlington, VA: American Psychiatric Publishing; 2008.

19. Rossi J, Swan MC, Isaacs ED: The violent or agitated patient. Emerg Med Clin North Am 2010, 28:235-256, x

20. Fava M: Psychopharmacologic treatment of pathologic aggression. Psychiatric Clin North Am 1997, 20:427-451.

21. Lane SD, Kjome KL, Moeller FG: Neuropsychiatry of aggression. Neurologic Clin 2011, 29:49-64, vii.

22. Mattson M, editor: Neurobiology of aggression: understanding and preventing violence Totowa, NJ: Humana Press; 2003.

23. Olvera, Rene L: Intermittent explosive disorder: epidemiology, diagnosis and management. CNS drugs 2002, 16:517-526.
24. Potter-Efron RT: Differential diagnosis of physiological, psychiatric and sociocultural conditions associated with aggression and substance abuse. J Chem Dependency Treat 1990, 3:37-59.

25. Schneider LS, Sobin PB: Non-neuroleptic medications in the management of agitation in Alzheimer's disease and other dementia: a selective review. Int J Geriatr Psychiatry 1991, 6:691-708.

26. Lewis DO, Pincus JH: Epilepsy and violence: evidence for a neuropsychotic-aggressive syndrome. J Neuropsychiatry Clin N 1989, 1:413-418

27. Rosenbaum A, Hoge SK: Head injury and marital aggression. Am J Psychiat 1989, 146:1048-1051.

28. Tardiff K: Concise Guide to Assessment and Management of Violent Patients Arlington, VA: American Psychiatric Publishing, Inc:; 1996.

29. Tardiff K: Unusual diagnoses among violent patients. Psychiatr Clin North Am 1998, 21:567-576.

30. Chermack ST, Blow FC: Violence among individuals in substance abuse treatment: the role of alcohol and cocaine consumption. Drug Alcohol Depend 2002, 66:29-37.

31. Goedhard LE, Stolker JJ, Heerdink ER, Nijman HL, Olivier B, Egberts TC: Pharmacotherapy for the treatment of aggressive behavior in general adult psychiatry: a systematic review. J Clin Psychiatry 2006, 67:1013-1024.

32. Huband N, Ferriter M, Nathan R, Jones H: Antiepileptics for aggression and associated impulsivity. Cochrane Database Syst Rev 2010, CD003499.

33. Bitter I, Czobor P, Dossenbach M, Volavka J: Effectiveness of clozapine, olanzapine, quetiapine, risperidone, and haloperidol monotherapy in reducing hostile and aggressive behavior in outpatients treated for schizophrenia: a prospective naturalistic study (IC-SOHO). Eur Psychiatry 2005, 20:403-408

34. McDougle CJ, Stigler KA, Posey DJ: Treatment of aggression in children and adolescents with autism and conduct disorder. J Clin Psychiatry 2003, 64:16.

35. Fleminger S, Greenwood R, Oliver D: Pharmacological management for agitation and aggression in people with acquired brain injury. Cochrane Database Syst Rev 2006, CD003299.

36. Stanford M, Anderson N, Lake S, Baldridge R: Pharmacologic treatment of impulsive aggression with antiepileptic drugs. Curr Treat Options Neurol 2009, 11:383-390

37. Haspel T: Beta-blockers and the treatment of aggression. Harv Rev Psychiatry 1995, 2:274-281.

38. Mercer D, Douglass AB, Links PS: Meta-analyses of mood stabilizers, antidepressants and antipsychotics in the treatment of borderline personality disorder: effectiveness for depression and anger symptoms. $J$ Pers Disord 2009, 23:156-174.

39. McQuade DV, Barrnett RJ, King BH: Pharmacological intervention in aggression. Neurobiology of Aggression: Understanding and Preventing Violence Totawa, NJ: Humana Press, Inc:; 2003, 289-313.

40. Comai S, Tau M, Pavlovic Z, Gobbi G: The psychopharmacology of aggressive behavior: a translational approach: part 2: clinical studies using atypical antipsychotics, anticonvulsants, and lithium. J Clin Psychopharmacol 2012, 32:237-260.

41. Barratt ES, Stanford MS, Felthous AR, Kent TA: The effects of phenytoin on impulsive and premeditated aggression: a controlled study. J Clin Psychopharmacol 1997, 17:341-349.

42. Bowden $\mathrm{CL}$, Grunze $\mathrm{H}$, Mullen J, Brecher M, Paulsson B, Jones M, Vagero M Svensson K: A randomized, double-blind, placebo-controlled efficacy and safety study of quetiapine or lithium as monotherapy for mania in bipolar disorder. J Clin Psychiatry 2005, 66:111-121.

43. Yatham LN, Paulsson B, Mullen J, Vagero AM: Quetiapine versus placebo in combination with lithium or divalproex for the treatment of bipolar mania. J Clin Psychopharmacol 2004, 24:599-606.

44. Campbell M, Adams PB, Small AM, Kafantaris V, Silva RR, Shell J, Perry R, Overall JE: Lithium in hospitalized aggressive children with conduct disorder: a double-blind and placebo-controlled study. J Am Acad Child Adolesc Psychiatry 1995, 34:445-453.

45. Craft M, Ismail IA, Krishnamurti D, Mathews J, Regan A, Seth RV, North PM: Lithium in the treatment of aggression in mentally handicapped patients. A double-blind trial. Br J Psychiatry 1987, 150:685-689.

46. Kafantaris V, Coletti DJ, Dicker R, Padula G, Kane JM: Lithium treatment of acute mania in adolescents: a large open trial. J Am Acad Child Adolesc Psychiatry 2003, 42:1038-1045. 
47. Masi G, Milone A, Manfredi A, Pari C, Paziente A, Millepiedi S: Effectiveness of lithium in children and adolescents with conduct disorder: a retrospective naturalistic study. CNS Drugs 2009, 23:59-69.

48. Worrall EP, Moody JP, Naylor GJ: Lithium in non-manic-depressives: antiaggressive effect and red blood cell lithium values. Br J Psychiatry $1975,126: 464-468$

49. Jones RM, Arlidge J, Gillham R, Reagu S, van den Bree M, Taylor PJ: Efficacy of mood stabilisers in the treatment of impulsive or repetitive aggression: systematic review and meta-analysis. Br J Psychiatry 2011, 198:93-98.

50. Sheard MH, Marini $\mathrm{L}$, Bridges $\mathrm{Cl}$, Wagner $\mathrm{E}$ : The effect of lithium on impulsive aggressive behavior in man. Am J Psychiatry 1976, 133:1409-1413.

51. Umhau JC, Dauphinais KM: Omega-3 polyunsaturated fatty acids and health. In Low-Cost Approaches to Promote Physical and Mental Health: Theory, Research and Practice. Edited by: L'Abate L. New York, NY Springer Publishing; 2007:87-101.

52. Simopoulos AP: Evolutionary aspects of diet: the omega-6/omega-3 ratio and the brain. Mol Neurobiol 2011, 44:203-215.

53. Werbach M: Nutritional influences on aggressive behavior. J Orthomol Med 1992, 7:45-51

54. Harris WS: Expert opinion: omega-3 fatty acids and bleeding-cause for concern? Am J Cardiol 2007, 99:44C-46C.

55. Mozaffarian D, Rimm EB: Fish intake, contaminants, and human health: evaluating the risks and the benefits. JAMA 2006, 296:1885-1899.

56. Hibbeln JR, Ferguson TA, Blasbalg TL: Omega-3 fatty acid deficiencies in neurodevelopment, aggression and autonomic dysregulation: opportunities for intervention. Int Rev Psychiatry 2006, 18:107-118.

57. Freeman MP, Hibbeln JR, Wisner KL, Davis JM, Mischoulon D, Peet M, Keck PE Jr, Marangell LB, Richardson AJ, Lake J, Stoll AL: Omega-3 fatty acids: evidence basis for treatment and future research in psychiatry. $J$ Clin Psychiatry 2006, 67:1954-1967.

58. Gesch CB, Hammond SM, Hampson SE, Eves A, Crowder MJ: Influence of supplementary vitamins, minerals and essential fatty acids on the antisocial behaviour of young adult prisoners randomised, placebocontrolled trial. Br J Psychiatry 2002, 181:22-28.

59. Zaalberg A, Nijman H, Bulten E, Stroosma L, van der Staak C: Effects of nutritional supplements on aggression, rule-breaking, and psychopathology among young adult prisoners. Aggress Behav 2010, 36:117-126.

60. Schoenthaler SJ, Bier ID: The effect of vitamin-mineral supplementation on juvenile delinquency among American schoolchildren: a randomized, double-blind placebo-controlled trial. J Altern Complement Med 2000, 6:7-17.

61. Murphy $C M$, Ting LA: Interventions for perpetrators of intimate partner violence: $A$ review of efficacy research and recent trends. Partner Abuse 2010, 1:26-44.

62. Clark DB: Pharmacotherapy for adolescent alcohol use disorder. CNS Drugs 2012, 26:559-569.

63. Williams SH: Medications for treating alcohol dependence. Am Fam Physician 2005, 72:1775-1780.

64. Ernst DB, Pettinati HM, Weiss RD, Donovan DM, Longabaugh R: An intervention for treating alcohol dependence: relating elements of Medical Management to patient outcomes with implications for primary care. Ann Fam Med 2008, 6:435-440.

65. Babcock JC, Green CE, Robie C: Does batterers' treatment work? A metaanalytic review of domestic violence treatment. Clin Psychol Rev 2004, 23:1023-1053.

66. Chemtob CM, Novaco RW, Hamada RS, Gross DM: Cognitive-behavioral treatment for severe anger in posttraumatic stress disorder. J Consult Clin Psychol 1997, 65:184-189.

67. Gondolf EW: Batterer programs. J Interpers Violence 1997, 12:83-98.

68. Lawson DM, Dawson TE, Kieffer KM, Perez LM, Burke J, Kier FJ: An integrated feminist/cognitive-behavioral and psychodynamic group treatment model for women who abuse their partners. Psychol Men Masculinity 2001, 2:86-99

69. Gondolf EW: A 30-month follow-up of court-referred batterers in four cities. Int J Offender Ther Comp Criminol 2000, 44:111-128.

70. Beck R, Fernandez E: Cognitive-behavioral therapy in the treatment of anger: a meta-analysis. Cogn Ther Res 1998, 22:63-74.
71. Coccaro E: In Aggression: Psychiatric Assessment and Treatment. Volume 22. Zug, Switzerland: Informa Healthcare; 2003.

72. Swenson CR, Sanderson C, Dulit RA, Linehan MM: The application of dialectical behavior therapy for patients with borderline personality disorder on inpatient units. Psychiatr Q 2001, 72:307-324.

73. Evershed S, Tennant A, Boomer D, Rees A, Barkham M, Watson A: Practicebased outcomes of dialectical behaviour therapy (DBT) targeting anger and violence, with male forensic patients: a pragmatic and noncontemporaneous comparison. Crim Behav Ment Health 2003, 13:198-213.

74. Maiuro RD, Eberle JA: State standards for domestic violence perpetrator treatment: current status, trends, and recommendations. Violence Vict 2008, 23:133-155.

75. Levesque DA, Ciavatta MM, Castle PH, Prochaska JM, Prochaska JO: Evaluation of a stage-based, computer-tailored adjunct to usual care for domestic violence offenders. Psychol Violence 2012, 1.

76. Taft CT, Murphy CM, Elliott JD, Morrel TM: Attendance-enhancing procedures in group counseling for domestic abusers. J Couns Psychol 2001, 48:51-60.

77. Horvath $A O$, Symonds BD: Relation between working alliance and outcome in psychotherapy: a meta-analysis. J Couns Psychol 1991, 38:139149.

78. Stone AA: The Tarasoff decisions: suing psychotherapists to safeguard society. Harv Law Rev 1976, 358-378.

79. Walcott DM, Cerundolo P, Beck JC: Current analysis of the Tarasoff duty: an evolution towards the limitation of the duty to protect. Behav Sci Law 2001, 19:325-43.

80. Kaur $G$, Herbert $L$ : Recognizing and intervening in intimate partner violence. Cleve Clin J Med 2005, 72:406-409.

81. Brown JL: Physicians have ethical, legal obligation to report child abuse. AAP News 2012, 33:20-20.

82. Houry D, Sachs CJ, Feldhaus KM, Linden J: Violence-inflicted injuries: reporting laws in the fifty states. Ann Emerg Med 2002, 39:56-60.

83. Geiderman J: Mandatory and permissive reporting laws: conflicts in patient confidentiality, autonomy, and the duty to report. In Ethical Problems in Emergency Medicine: a Discussion-based Review.. 1 edition. Edited by: Jesus J, Rosen P, Adams J, Derse AR, Grossman SA, Wolfe R. Hoboken, NJ: Wiley-Blackwell; 2012:271-285.

84. Felthous AR: The clinician's duty to protect third parties. Psychiatr Clin North Am 1999, 22:49-60.

85. Beck JC: Legal and ethical duties of the clinician treating a patient who is liable to be impulsively violent. Behav Sci Law 1998, 16:375-89.

86. Yudofsky S, Stevens L, Silver J, Barsa J, Williams D: Propranolol in the treatment of rage and violent behavior associated with Korsakoff's psychosis. Am J Psychiatry 1984, 141:114-115.

87. Látalová K: Bipolar disorder and aggression. Int J Clin Pract 2009, 63:889-899.

88. Boles SM, Miotto K: Substance abuse and violence: a review of the literature. Aggress Violent Behav 2003, 8:155-174.

89. Tuninger EE, Levander S, Bernce R, Johansson G: Criminality and aggression among psychotic in-patients: frequency and clinical correlates. Acta Psychiatr Scand 2001, 103:294-300.

90. d'Orbán PT, Dalton J: Violent crime and the menstrual cycle. Psychol Med 1980, 10:353-359.

91. Barlow DH: Anxiety and its Disorders. The Nature and Treatment of Anxiety and Panic New York, NY: The Guilford Press; 2004.

92. Kernberg OF: Aggression in Personality Disorders and Perversions. New Haven, CT: Yale University Press; 1995

93. Loney J: Hyperactivity and aggression in the diagnosis of attention deficit disorder. In Advances in clinical child psychology. Volume 10. Edited by: Lahey BB, Kazdin AE. New York, NY: Plenum Press; 1987:99-135.

94. Feldbau-Kohn S, Heyman RE, O'Leary KD: Major depressive disorder and depressive symptomatology as predictors of husband to wife physical aggression. Violence Vict 1998, 13:347-360.

95. Villano JL, Mlinarevich N, Watson KS, Engelhard HH, Anderson-Shaw L: Aggression in a patient with primary brain tumor: ethical implications for best management. J Neuro-Oncol 2009, 94:293-296.

96. Dickson DW, Davies P, Mayeux R, Crystal H, Horoupian DS, Thompson A, Goldman JE: Diffuse Lewy body disease. Acta neuropathologica 1987 75:8-15. 
97. Benedict RH, Shapiro A, Priore R, Miller C, Munschauer F, Jacobs L: Neuropsychological counseling improves social behavior in cognitivelyimpaired multiple sclerosis patients. Mult Scler 2000, 6:391-396.

98. Kito Y, Kazui H, Kubo Y, Yoshida T, Takaya M, Wada T, Nomura K, Hashimoto M, Ohkawa S, Miyake H: Neuropsychiatric symptoms in patients with idiopathic normal pressure hydrocephalus. Behav Neurol 2009, 21:165-174.

99. Rosenblatt A, Leroi I: Neuropsychiatry of Huntington's disease and other basal ganglia disorders. Psychosomatics 2000, 41:24-30.

100. Orengo CA, Khan J, Kunik ME, Snow AL, Morgan R, Steele A, Cully JA, Graham DP: Aggression in individuals newly diagnosed with dementia. Am J Alzheimers Dis Other Demen 2008, 23:227-232.

101. Golden CJ, Jackson ML, Peterson-Rohne A, Gontkovsky ST: Neuropsychological correlates of violence and aggression: A review of the clinical literature. Aggress Violent Beh 1996, 1:3-25.

102. Rayel MG, Land WB, Gutheil TG: Dementia as a risk factor for homicide. $J$ Forensic Sci 1999, 44:565-567.

103. Hector $M$, Burton JR: What are the psychiatric manifestations of vitamin $B_{12}$ deficiency? J Am Geriatr Soc 1988, 36:1105-1112.

104. Lonsdale D, Shamberger RJ: Red cell transketolase as an indicator of nutritional deficiency. Am J Clin Nutr 1980, 33:205-211.

105. Werbach M: Nutritional influences on aggressive behavior. J Orthomol Med 1992, 7:45-51

106. Liu J, Raine A: The effect of childhood malnutrition on externalizing behavior. Curr Opin Pediatr 2006, 18:565-570.

107. Schrauzer GN, Shrestha KP: Lithium in drinking water and the incidences of crimes, suicides, and arrests related to drug addictions. Biol Trace Elem Res 1990, 25:105-113.

108. Rasmussen HH, Mortensen PB, Jensen IW: Depression and magnesium deficiency. Int J Psychiatry Med 1989, 19:57-63.

109. Branchey L, Branchey M, Shaw S, Lieber CS: Depression, suicide, and aggression in alcoholics and their relationship to plasma amino acids. Psychiatry Res 1984, 12:219-226.

110. Giancola PR, Corman MD: Alcohol and aggression: a test of the attentionallocation model. Psychol Sci 2007, 18:649-655.

111. Licata A, Taylor S, Berman M, Cranston J: Effects of cocaine on human aggression. Pharmacol Biochem Behav 1993, 45:549-552.

112. Gottschalk LA, Rebello T, Buchsbaum MS, Tucker HG, Hodges EL: Abnormalities in hair trace elements as indicators of aberrant behavior. Compr Psychiatry 1991, 32:229-237.

113. Singh S, Sharma N: Neurological syndromes following organophosphate poisoning. Neurol India 2000, 48:308-313.

114. Henry J: Drug overdose, drugs of abuse and hypermetabolism. In Hyperthermic and Hypermetabolic Disorders: Exertional Heat-stroke, Malignant Hyperthermia and Related Syndromes. Edited by: Hopkins PM, Ellis FR. Cambridge, UK: Press Syndicate of the University of Cambridge; 1996:239-258.

115. Blacker K: Aggression and the chronic use of LSD. J Psychoactive Drugs 1970, 3:32-37

116. Gerra G, Zaimovic A, Raggi MA, Giusti F, Delsignore R, Bertacca S, Brambilla F: Aggressive responding of male heroin addicts under methadone treatment: psychometric and neuroendocrine correlates. Drug Alcohol Depend 2001, 65:85-95.

117. Anderson PD, Bokor G: Forensic Aspects of Drug-Induced Violence. Journal of Pharmacy Practice 2012, 25:41-49.

118. DiMascio A: The effects of benzodiazepines on aggression: reduced or increased? Psychopharmacology 1973, 30:95-102.

119. Williams ER, Shepherd SM: Medical clearance of psychiatric patients. Emerg Med Clin North Am 2000, 18:185-198.

120. Benton D, Kumari N, Brain PF: Mild hypoglycaemia and questionnaire measures of aggression. Biol Psychol 1982, 14:129-135.

121. Rahman $\mathrm{T}$, Hodgson $\mathrm{H}$ : Clinical management of acute hepatic failure. Intensive Care Med 2001, 27:467-476.

122. Gupta N, Midha P, Singh G: Psychiatric aspects of endocrine disorders. In Recent Advances Pediatrics: Pediatric Endocrinology. Special Volume 13. Edited by: Gupte S. New Delhi: Jaypee Brothers Medical Publishers; 2004:308.

123. Trafford PA: Homicide in acute porphyria. Forensic Sci 1976, 7:113-120.

124. Berkowitz L: Pain and aggression: some findings and implications. Motivation Emotion 1993, 17:277-293.

125. Soldatos C, Kales A: Sleep disorders: research in psychopathology and its practical implications. Acta Psychiatr Scand 1982, 65:381-387.
126. Arai A, Ishii T, Yasui T, Takahashi A, Ishigooka J, Murakaki M: A case of iron deficiency anemia with delirium. Kanagawaken Seishin lgakkaishi 1998, 48:31-36.

127. Simpson TL, Saxon AJ, Meredith CW, Malte CA, McBride B, Ferguson LC, Gross CA, Hart KL, Raskind M: A pilot trial of the alpha-1 adrenergic antagonist, prazosin, for alcohol dependence. Alcohol Clin Exp Res 2009, 33:255-263.

128. Kaplan BJ, Crawford SG, Gardner B, Farrelly G: Treatment of mood lability and explosive rage with minerals and vitamins: two case studies in children. J Child Adolesc Psychopharmacol 2002, 12:205-219.

129. Yudofsky S, Williams D, Gorman J: Propranolol in the treatment of rage and violent behavior in patients with chronic brain syndromes. Am J Psychiatry 1981, 138:218-220.

130. Stanford MS, Houston RJ, Mathias CW, Greve KW, Villemarette-Pittman NR, Adams D: A double-blind placebo-controlled crossover study of phenytoin in individuals with impulsive aggression. Psychiatry Res 2001, 103:193-203.

131. Coccaro EF, Kavoussi RJ: Fluoxetine and impulsive aggressive behavior in personality-disordered subjects. Arch Gen Psychiatry 1997, 54:10811088.

132. George DT, Phillips MJ, Lifshitz M, Lionetti TA, Spero DE, Ghassemzedeh N, Doty L, Umhau JC, Rawlings RR: Fluoxetine treatment of alcoholic perpetrators of domestic violence: a 12-week, double-blind, randomized, placebo-controlled intervention study. J Clin Psychiatry 2011, 72:60-65.

133. Sultzer DL, Gray KF, Gunay I, Berisford MA, Mahler ME: A double-blind comparison of trazodone and haloperidol for treatment of agitation in patients with dementia. Am J Geriatr Psychiatry 1997, 5:60-69.

134. Buckley PF: The role of typical and atypical antipsychotic medications in the management of agitation and aggression. J Clin Psychiatry 1999, 60(suppl 10):52-60.

\section{Pre-publication history}

The pre-publication history for this paper can be accessed here: http://www.biomedcentral.com/1741-7015/10/146/prepub

\section{doi:10.1186/1741-7015-10-146}

Cite this article as: Umhau et al:: The physician's unique role in preventing violence: a neglected opportunity? BMC Medicine 2012 10:146.

\section{Submit your next manuscript to BioMed Central and take full advantage of:}

- Convenient online submission

- Thorough peer review

- No space constraints or color figure charges

- Immediate publication on acceptance

- Inclusion in PubMed, CAS, Scopus and Google Scholar

- Research which is freely available for redistribution 